\title{
Archetypal Symbols in the Symphonic Poem The Sea by Mikalojus Konstantinas Čiurlionis
}

\author{
Martina Štěpánová / martina.samajova@seznam.cz \\ Department of Music Education, Pedagogical Faculty, University of Ostrava, CZ
}

David Kozel / david.kozel@osu.cz

Department of Music Education, Pedagogical Faculty, University of Ostrava, CZ

\begin{abstract}
We find many symbolic legacies in the creative and musical work of Lithuanian music composer and painter Mikalojus Konstantinas Čiurlionis (1875-1911). He processed cosmological, religious, national Lithuanian and natural motifs. The symphonic poem titled Jūra (The Sea) from 1907 is saturated with archetypal symbols of the natural elements with a philosophical overlap. The study focuses on the analysis and interpretation of selected musical symbols in the structure of the work. The initially onomatopoeia effects of the composition get new significance and contexts during archetypal performance. The archetypal symbols of the composition refer to the patterns of the life cycle on the background of the ambivalent water element. The study has the objective to newly interpret the symphonic poem Jüra in the context of archetypal symbolism.
\end{abstract}

\section{Key words}

Mikalojus Konstantinas Čiurlionis, The Sea, sea, water, archetype, musical symbol, symphonic poem, onomatopoeia, Lithuania 


\section{Introduction}

The central figure of Lithuanian music Mikalojus Konstantinas Čiurlionis (1875-1911) was in his works further inspired by natural symbols with a number of ambiguous meanings. The strong symbolic inspiration from the natural elements in his musical compositions encourages the search for remarkable interpretative approaches to uncover their potential significance in the context of Lithuanian and European music culture at the turn of the 19th and 20th centuries. Even if the works of Čiurlionis in terms of style fall under Late Romanticism, the author targeted the modern style, which synthesises the national (Lithuanian) musical inspiration with the European context of Late Romanticism (specific polyphony works, ostinati, expansion of tonality and modality). The traditional concept of a symphonic poem in his case is combined with the concept of nature in the philosophical, aesthetic, spiritual and mythological sense. The link of the archetype symbol of water with mythologically significant ranks his symphonic poem Jüra (1907, hereinafter The Sea) to the narrow relationship with the symphonic work of Jean Sibelius (Finnish mythology), Richard Strauss (symphonic poems inspired by philosophy and nature), Alexander N. Scriabin (philosophy and mysticism, the fire element), Vítězslav Novák (nature and folklore as an inspiring source), but also Claude Debussy, ${ }^{1}$ Ottorino Respighi (natural elements in poetics of impressionism). The significance of Čiurlionis' works in European musical culture is intensively evaluated only on the basis of the musicological production of the last decades. ${ }^{2}$ As Eero Tarasti comments: "The true Lithuanian identity of his music is in its structural properties and unique artistic inter relation ships. He also represents an interesting case in which the National is transformed into the Modern."3

1 The sea (water) was a frequent symbol in the compositions in Late Romanticism and Impressionism. At the turn of the last century Claude Debussy in his La Mer (1905), just like Čiurlionis and his poem The Sea (1903-1907), very dramatically and emotionally depicts the Sea. Both orchestral works were composed in the same period independent of each other and show different composition styles. The touch points are the image of the Sea as a source of mystery in contrast with Romantic aesthetics. Debussy and Čiurlionis were influenced by the "Sea" images of William Turner. For details, refer to ARIAS, Enrique Alberto. Sublimity and Nature: M. K. Čiurlionisś Jura. Lituanus Lithuanian Quarterly Journal of Arts and Sciences [online]. 2001, Vol. 47, No. 3. [2019-10-12]. http://www.lituanus.org/2001/01_3_04.htm.

2 We at least selectively refer to some titles from a relatively recent period, which provide source support to the topic of this study. LANDSBERGIS, Vytautas. M. K. Cínrlionis: Time and Content. Vilnius: Lituanus, 1992. GOŠTAUTAS, Stasys - Birute VAIČJURGIS-ŠLEŽAS. Čiurlionis: painter and composer: collected essays and notes, 1906-1989, with 209 illustrations. Vilnius: Vaga, 1994. KIMBRYS, Petras. Mikalojus Konstantinas Čiurlionis: twórczość, osobowość, środowisko. Nacionalinis M. K. Čiurlionio dailès muziejus, 2001. Dialogues of Colour and Sound: Works by Mikalojus Konstantinas Ciurlionis and His Contemporaries. Lithuanian Art Museum, 2009. KEYM, Stefan. Landschaftsmalerei versus Sonatenform. Die symphonischen Dichtungen Miške und Jura von M. K. Čiurlionis. Musicology of Lithuania/Lietuvos muzikologija. 2009, t. 10., pp. 8-28. KAZOKAS, Genovaité. Musical Paintings: Life and Workof M. K. Čiurlionis (1875-1911). Vilnius: Logotipas, 2009. DAUNORAVIČIENĖ, Gražina - Rima POVILIONIENE. Mikalojus Konstantinas Čiurlionis (1875-1911): jo laikas ir mūsu laikas : stduiju ir mokslo straipsniu rinkinys. Vilnius: Lietuvos muzikos ir teatro akademija, 2013.

3 TARASTI, Eero. Semiotics of Classical Music: How Mozart, Brahms and Wagner Talk to Us. Berlin: De Gruyter, 2012, p. 370. 


\section{The Sea as a musical composition}

Water as one of the four major natural elements was intensively elaborated by Čiurlionis using musical and artistic resources. In painting, this concerns an extensive number of individual paintings and triptychs. ${ }^{4}$ In the musical field, he considered the water level in the piano work The Sea, cycle of landscapes for piano from 1908 and in the already stated symphonic poem The Sea from 1907. The symphonic poem The Sea was composed between 1903 and 1907 and is dedicated to Čiurlionis' Warsaw friend Mrs. B. Wolman. During the visit to the Wolman Summer House in Crimea, Čiurlionis has the opportunity to get a direct aesthetic experience of the Black Sea, which differs from the Baltic Sea in terms of character. ${ }^{5}$ The symphonic poem had its posthumous première in 1936 in Kaunas (Lithuania) on the occasion of the $25^{\text {th }}$ anniversary of the composer's death. In 1990, during the 115th anniversary of Čiurlionis' death, the initial composition had its première. The scope of the work, its complexity and demanding composition approach of the author indicate that the composer perceived this symphonic poem as a work that summarises his philosophical and musical thinking. The composition is conceived for a big romantic orchestra with significant use of the harp. ${ }^{6}$

The symphonic poem The Sea is written in a free sonata form. It contains the following parts: exposition (Andante: 1-65 b., Allegro moderato: 66-92 b., Meno mosso: 93-139 b., Andante sostenuto: 140-197 b.), development (Allegro Moderato: 198-221 b., Meno mosso: 222-230 b., Allegro: 231-360 b.) and recapitulation (Maestoso: 361-388 b., Andante: 389-440 b., Allegro moderato: 441-543 b., Andante cantabile: 544-575 b.) with coda (Andante maestoso: $576-607$ b.). ${ }^{7}$ The approximate duration of the performance of the composition is 31 minutes with a total of 607 bars. The specific characteristic of the sonata arrangement are the musical thoughts, which by their scope do not typically take the form of late-romantic themes. The core of the musical ideas are the shorter motifs and their evolutionary development and changes in shape. The composition is symbolically permeated by two central ideas. It concerns a grim monotone idea of danger and an overwhelming storm and a brightly sparking idea that celebrates the size and breadth of the sea, infinity, overlap into other realms. The thinking contrast in music is combined with the ambivalent symbolism of water in the form of the sea, which also provides an aesthetic reflection of different expressive forms (storm and calm, static and dynamic nature, etc.). The composition also contains quotations of folk melodies

4 Triptych Sonata of the Sea (1908), paintings The Sun is Passing the Sign of Libra, The Sun is Passing the Sign of Aquarius, The Sun is Passing the Sign of Pisces (1906-1907), Serenity (1903-1904), Prelude (1908), Lichtning (1909), Sea at Night (1906), etc. List of creative works, see Ciurlionis.eu [online]. [21/10/2019]. http://ciurlionis.eu/en/ painting/gallery.

5 The composer's so intensively reflected aesthetic experience with the natural elements in Czech music has its potential parallel in Vítězslav Novák (1870-1949) whose work also combines mystical experience with nature and pantheism. Let's mention two significant examples: the symphonic poem In the Tatras (V Tatrách, 1902) and the piano cycle Pan (Pan, 1910) with part of The Sea (More).

6 For details of the genesis of the composition, see for instance ARIAS, op. cit.

7 The analysis of the form and tectonic arrangement is given by KEYM, op. cit., p. 27. 
Motule mano (My Dear Mother, see commentary to the Great Mother below, in which is possible to discern the author's strong relationship and patriotism to his native Lithuania). Landsbergis states that the style of the composition is influenced by Late Romanticism, specifically, for instance, the echo of the technique in the case of Richard Wagner and Richard Strauss. ${ }^{8}$ The composition is tectonically conceived in large overlapping sections with the greatest kinetic activity at the middle of the work. The recapitulation of the symphonic poem narratively returns to the thematic material of the exposition, but is transformed thanks to the colourfully conceived instrumentation. The size and extent of the sea are shown as aesthetic qualities not only in macro-tectonic dimensions of the work but also in many ostinato motifs (figures, a typical characteristic particularly of Čiurlionis' piano music) and in the intellectually supporting thematic sections. In the composition, Čiurlionis often creates high peaks and gradations in order to express the strength and danger hidden in the sea. The composition also features modal sections, particularly in connection with the quotation of the Lithuanian folk song Motule mano, which creates an aura of folklore and anthem type. ${ }^{9}$

\section{The Sea as an archetypal symbol}

The archetypal interpretation of Čiurlionis' composition The Sea is methodologically based on the theory of archetypes from Carl Gustav Jung (1875-1961) and the existence of collective unconscious. ${ }^{10}$ Jung explains the initial definition of the archetype by its oblivious aspect, which gets into the consciousness in variegated manifestations according to the specific culture and artistic medium: "The archetypes is essentially an unconscious content that is altered by becoming conscious and by being perceived, and it takes its colour from the individual consciousness in which it happens to appear." 11 According to Jung, becoming conscious of the archetypes occurs in a secondary manner and they are perceived as "pre-existing forms", specification of the manifestation of archetypes occurs through symbolisation in connection with the cultural differences, but also the individual and collective experiences of man. Art is one of the significant manifestations of archetypal symbols. The archetypal contents of art prove the universal motifs and shapes that exist in parallel without any dependency on the given culture and their manifestation period. Apart from the unconscious aspect of the archetypal symbolisation, culture also has a secondary presence of the more or less conscious aspect of the artistic handling of culturally established symbols and motifs, which refer to their archetypal origin, for instance, in the myth. Even if Jung did not address the problems of the symbolisation of archetypes in music, the problems of archetypes in music are recently becoming a

8 LANDSBERGIS, op. cit., p. 65.

9 ARIAS, op. cit.

10 JUNG, Carl Gustav. The Archetypes and the Collective Unconscious. Princeton: Princeton University Press, 1969. JUNG, Carl Gustav et al. Man and his Symbols. New York: Dell Publishing Company, 1968.

11 JUNG, Carl Gustav. The Archetypes and the Collective Unconscious, p. 5. 
regular area for application of the theory of archetypes in musicology. ${ }^{12}$ An important implication of the archetypal interpretation in music is the concept of the symbol, which is different from the traditionally applied linguistic and semiotic line of the symbol as the representative characteristic. The symbols are related to the unconscious aspect, as the characteristics of intellect and consciousness. In this context, Jung comments: "Thus a word or an image is symbolic when implies something more than its obvious and immediate meaning. It has a wider 'unconscious' aspect that is never precisely defined or fully explained." 13 The music symbols are punctuated by unconscious aspects that our conscious does not capture precisely, but also culturally conventionalised characteristics and traditions.

During the following analysis of the music, we comprehend the theme of the water (respectively sea) element as an archetypal symbol of unconscious, which is manifest in artistic work in phenomenally different ways. Water and aesthetic experience with it is a typical example of archetypal symbolisation. ${ }^{14}$ Water as an element symbolises the continuous process of change; it is ambivalent in terms of significance and nature. ${ }^{15}$ We base our interpretation of the archetypal symbolisation of water in the case of Čiurlionis' composition on the interpretation of the significance of water, which is related to specific musical expression and its resources. The archetypal significance of water is symbolised in the music composition while respecting the stylish and purely musical nature. We methodologically seek a symbol, metaphor or rising sound of water as a symbol in the musical structure. An additional interpretation method is amplification of the significance of the water symbol in a work of music using analogous musical, but also cultural significances. Due to the predominant creative focus of Čiurlionis' works, we approach the score of the composition also from the creative (spatial) viewpoint.

It is not the objective of this text to make an archetypal interpretation of the whole composition, but we selected three symbolic images on which we shall demonstrate the given procedure and characteristics of selected relationships between the archetypal sea and the musical expression of Čiurlionis. This concerns three analytical insights that illustrate the potential interpretation approach. Firstly, this concerns the opening part of the composition itself, which we call the symbol of birth, a new beginning. This is followed by a selected demonstration of block instrumentation in the score with emphasis on the musical expression of changes in the water; this concerns the symbol of washing/ purification, and also includes the visualisation of the stated phenomena. The third symbolical image is at the end of the composition and refers to the ambivalence of the sea in the form of symbolisation of melancholy and triumph.

12 ADAMENKO, Victoria. Neo-Mythologism in Music. From Scriabin and Schoenberg to Schnittke and Crumb. NY, Hillsdale: Pendragon Press, 2007. TARASTI, Eero. Myth and Music: A Semiotic Approach to the Aesthetics of Myth in Music, especially that of Wagner, Sibelius and Stravinsky. Helsinki: Suomen Musiik kitieteellien Seura, 1978. KOZEL, David. Mythological Archetype in Music and Principles of its Interpretation. International Review of the Aesthetics and Sociology of Music, 2016, Vol. 47, No. 1, pp. 3-15.

13 JUNG, Carl Gustav et al. Man and his Symbols, p. 4.

14 We comprehend the aesthetic experience in the style of the aesthetics of the elements according to Gaston Bachelard. See BACHELARD, Gaston. Water and Dreams: An Essay on the Imagination of Matter. Texas, Dallas: Dallas Inst Humanities \& Culture, 1999.

15 KALNICKÁ, Zdeňka. Water and Woman: Symbolic-Aesthetic Archetype. Berlin: VDM publishing house Itd., 2010. 


\section{Symbol of birth}

The symphonic poem starts with a rising scale in E major through four octaves in harp (see Example 1). This scale (passage) creates a gesture - like a rushing wave - which changes frequently and recurs. The wave peaks in a violin two-bar motif $\left(\mathrm{e}^{3}\right.$-gis $\left.{ }^{3}-\mathrm{cis}^{3}-\mathrm{h}^{2}\right)$, which is followed by a new clarinet and flute motif with quarto-quint characteristics. ${ }^{16}$

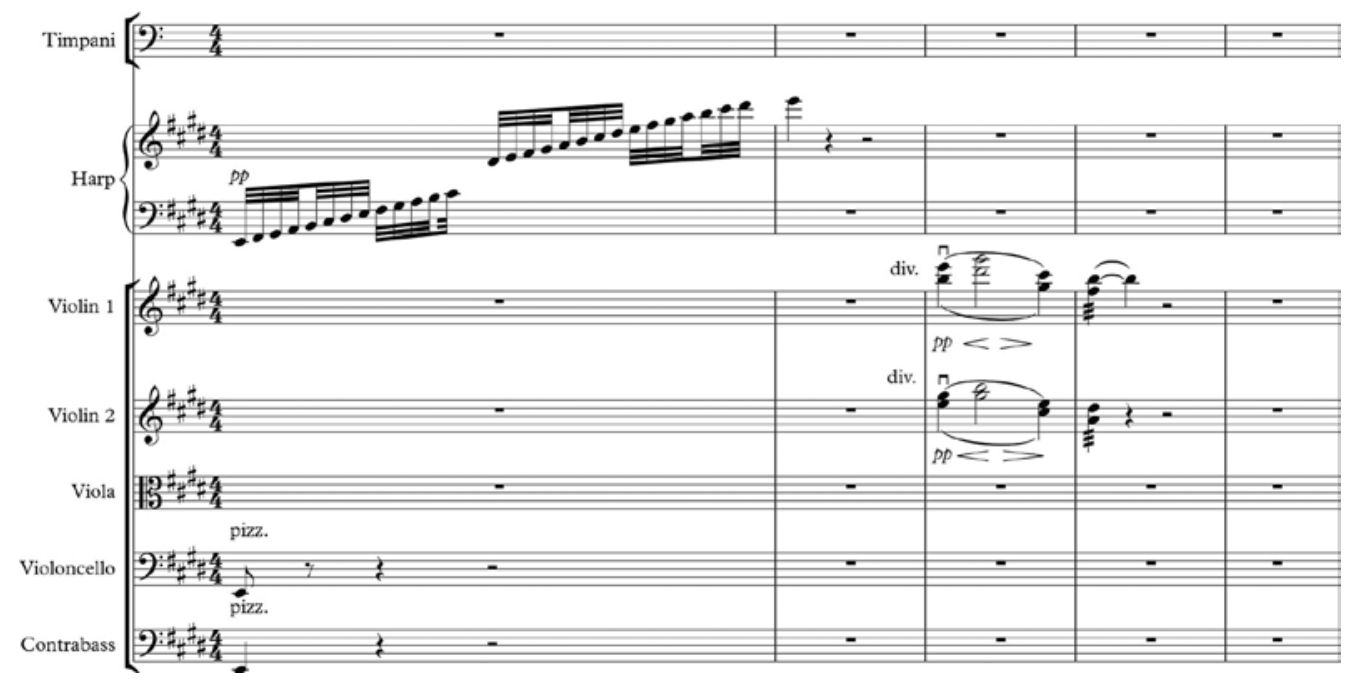

Ex. 1 The rising harp E major, quarto-quint motif of the initial part of the composition (bars 1-3). ČIURLIONIS, Mikalojus Konstantinas. The Sea. [orchestral score] Leningrad: Muzyka, 1965.

The inspiration from the natural themes and cosmology that is typical for Čiurlionis was related to the aesthetics of the Romantic period, Lithuanian folklore and the return to the mythological symbol of Great Mother, the unflagging source of everything and everything that returns to it again. The harp motif of the mythologically perceived beginning of the composition depicts the use of small notes in high motion and increase of the sea waves, with which the process of mythological birth starts. The wave is characterised as a variable, moving and unstable phenomenon. In terms of analytical psychology, it is characteristic by its dynamic energy, creative force, which drives the psychic life ahead, helps in getting to the archetypal transition. ${ }^{17}$ The opening harp beginning by its outfall into the motif of the symphony evokes a mythical period of timelessness in

16 The similarity of the first motif on the theme of the symphonic poem Vyšehrad by Bedřich Smetana and the identical instrumentation application of the harp is pointed out by KEYM, op. cit, pp. 12-13.

17 JUNG, Carl Gustav. Symbols of Transformation. Collected Works Volume Five. New York: Routledge, 1956. 
which the world was created. Čiurlionis achieves this effect also by symbolic selection of the harp as a typical mythical instrument. We can associate the harp with kankles, the traditional instrument of the Baltics (zither-chordophone). The harp scale (passage) is a gesture of the creative birth from the water element. The opening motif of the composition is a variable dynamic wave (birth), which we make analogous to the The Birth of Venus (cca 1485) by Sandro Botticelli. ${ }^{18}$ In this motif, the Roman Goddess of Beauty, Venus, born of sea froth, swims in on the rocking sea waves, shown in a sea shell, where we would usually search for a pearl (symbol of all water force, indicates birth, the female principle of the Ocean).

We comprehend the harp motif as a visualisation of the diagonal from the left lower corner of the score and imaginary musical space toward the upper right corner. For Čiurlionis' synaesthetic perception, it is therefore possible that this phenomenon is also a creative composition target. Wassily Kandinsky ${ }^{19}$ explains the diagonal as one of three basic lines used in the visual arts. It is precisely at centre between the horizontal, which is the cold stable plane that can expand in all directions and the vertical, the warm height line. The centre diagonal is in its internal expression the synthesis of the warm and cold poles and is eccentric in the score of Čiurlionis' musical work; its tension spreads in the flatness and does not have a tendency to move away from this position. The visualisation of the diagonal leads to the beginning, it continues to be a rising motion. Kandinsky further says the following on the geometrical line phenomenon: „The geometric line is an invisible thing. It is the track made by the moving point; that is, its product. It is created by movement-specifically through the destruction of the intense self-contained repose of the point. Here, the leap out of the static into the dynamic occurs." ${ }^{20}$ The association and support of the idea of the variable dynamic character of the sea waves, which sounds movable in the unit of time, not only in music but also in music and the visual imaginary space, is typical for symbolisation of water in Čiurlionis' composition The Sea. The harp symbol here is tied to the significance of transition to another world (the act of birth), transposed to a bigger universe, cosmos, toward God.

\section{The washing symbol}

A further characteristic place in Čiurlionis' symphonic poem is the visual and audio capturing of the variability of the sea water level in several sections of the composition. It concerns complex symbolic images, which are accompanied in the musical record by block instrumentation and differentiated scoring of the individual voices (see Example 2).

18 Ottorino Respighi let himself be inspired by this image in the composition Trittico Botticelliano (1927), where he captures the sea waves and grandiose coming of Venus in a very similar onomatopoeic procedure.

19 KANDINSKY, Wassily. Point and Line to Plane. New York: Solomoner R. Guggenheim Foundation New York, 1947, p. 59.

20 Ibid., p. 57. 


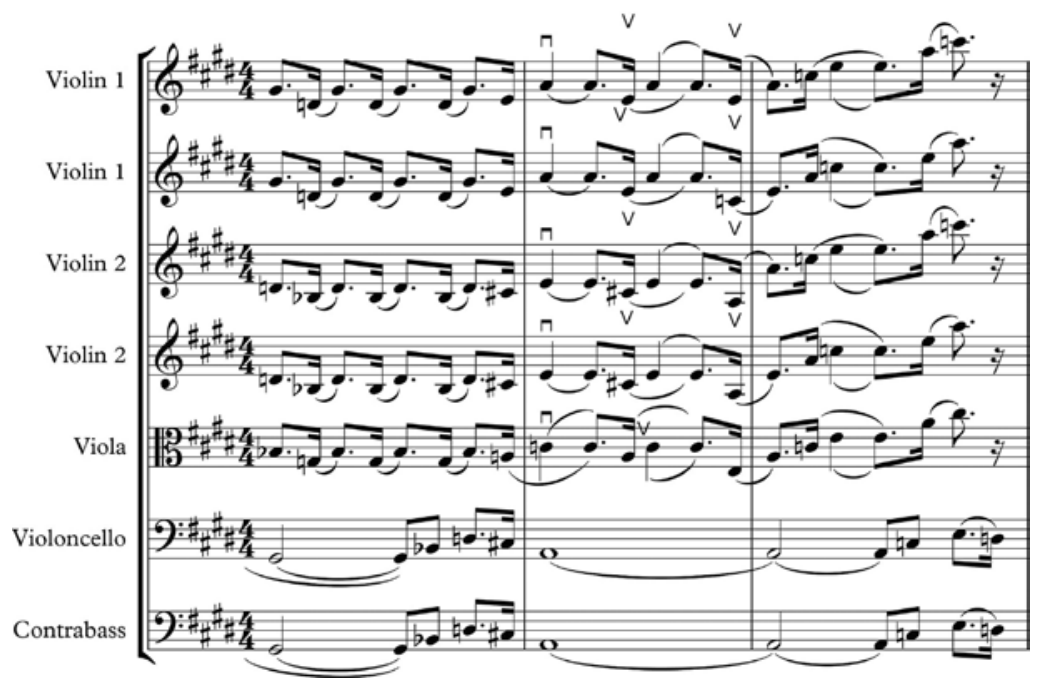

Ex. 2 Imitation of the sea waves in the string instruments (bars 81-83), in the part Allegro moderato. ČIURLIONIS, Mikalojus Konstantinas. The Sea. [orchestral score] Leningrad: Muzyka, 1965.
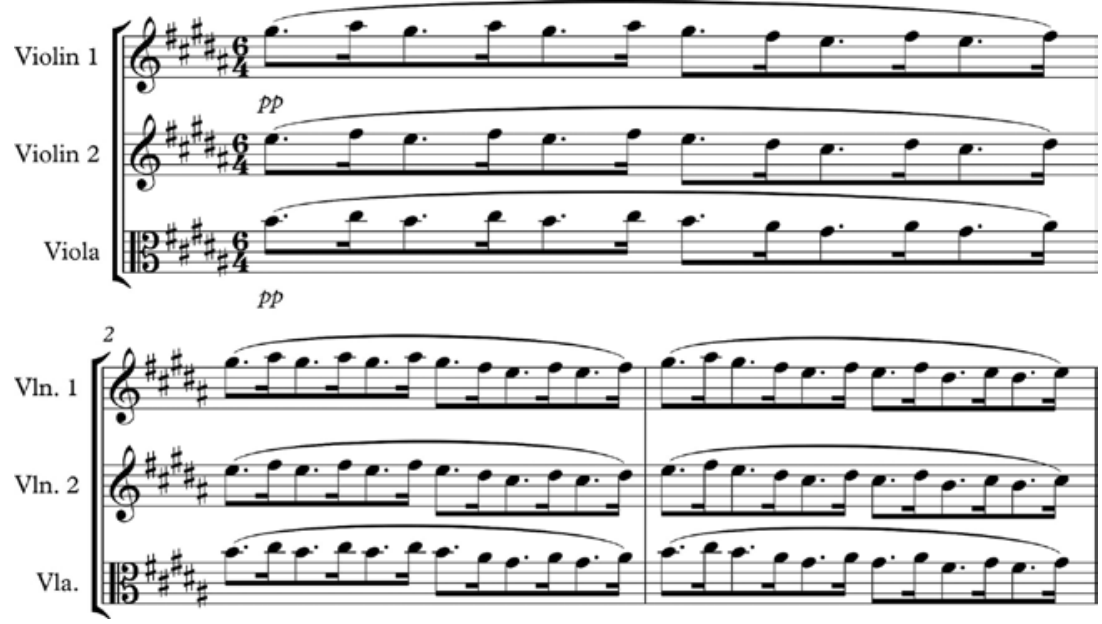

Ex. 3 Imitation of the sea waves in the string instruments (bars 1-3), the The Birth of Venus from Trittico Botticelliano by Ottorino Respighi. RESPIGHI, Ottorino. Trittico Botticelliano. [orchestral score]. Milan: Ricordi, 1928.

Potential symbolic amplification to this depiction of the swelling of the waves is, for instance, already mentioned in the composition Trittico Botticelliano (1927) by Ottorino Respighi, where immediately in the opening of the third part of the triptych (The Birth of Venus) similarly imitates the motion in the string instruments group (see Example 3). 
Respighi in the introduction to this section uses instruments the violoncello and harp (this symbolic instrument again).

The use of string instruments is understandable because their softness and sound evoke the murmur of the crashing waves and foaming of the sea. The wave as already stated above refers to instability, variable, to the process of washing, purification. Use of the dotted rhythm in both stated examples is at the next interpretation level an iconic movement similar to the movement of the sea level in the waves. Illustrative example of the rising waves as a symbol is clear in the score in the following example (see Example 4), where by partial imitation and diminution of the tone material and gradual increasing of the tone from the deeper to the higher instrument levels.

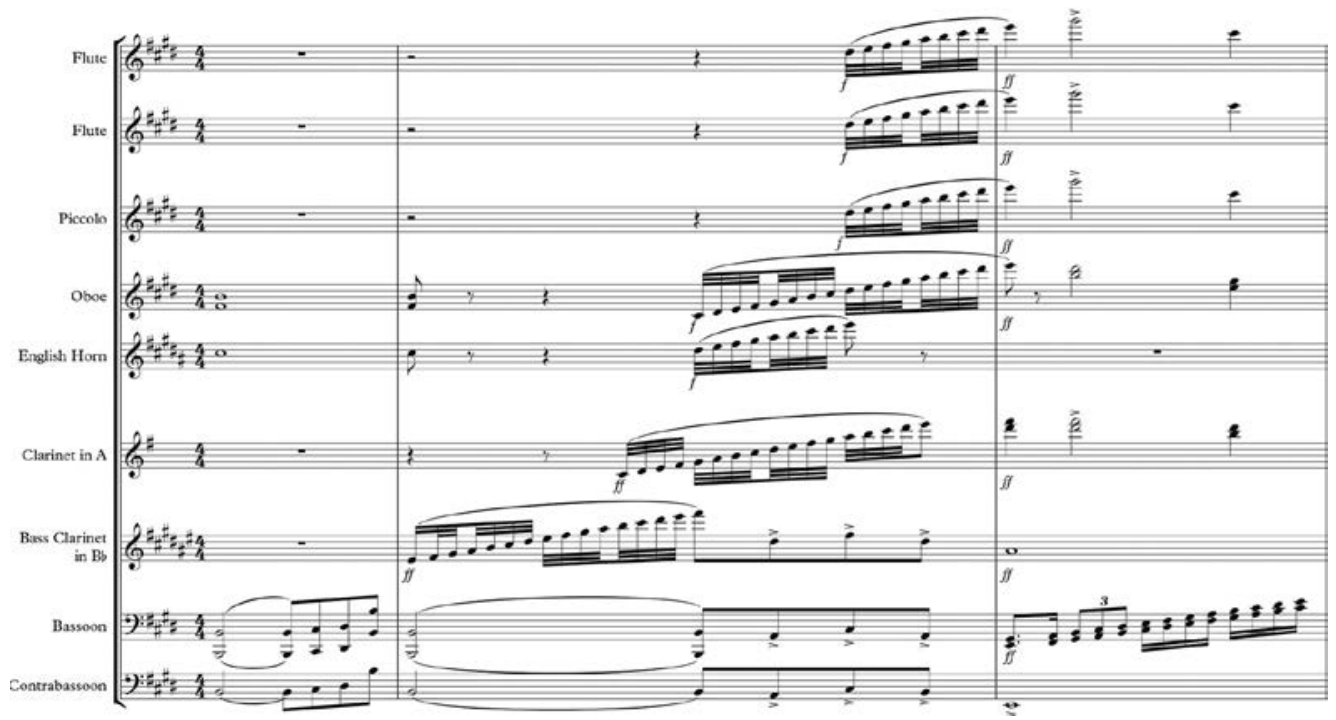

Ex. 4 Audio and visual imitation of the rising waves (bars 362-364), the part Maestoso from the The Sea. ČIURLIONIS, Mikalojus Konstantinas. The Sea. [orchestral score] Leningrad: Muzyka, 1965.

\section{Symbols of melancholy and triumph}

The third analytical view concerns the coda marked Andante maestoso. The opening key of the coda e minor is at the middle of the musical flow transformed into the same ceremonial key $\mathrm{E}$ major. This final section of the symphonic poem is a synthesising and reminiscent moment in which the ambivalence of the water element is musically expressed in the form of the symbols of melancholy and triumph. ${ }^{21}$ The beginning of the coda is instrumentally carried by the sound of the organ, which (with the support of the

21 KEYM, op. cit., pp. 17-18. 
contra basses) are transformed into the "e" tone that accentuates the musical expression of the mythical timelessness. The described music score is enriched with a distinctive syncopated and dotted motif in the bassoon (see Example 5). The rhythmic-melodious bassoon motif at first is imitated by the violoncello, later by the whole string section. Increase of the colourfulness of the orchestration accentuates the musical aspects here by the urgency and intensity of the non-musical message. The entire first half of the coda makes the impression of a repetitive and static loop, a recurring minimalist cloud above the imaginary mysterious water body. By these musical resources, Čiurlionis returns to the mythical timelessness in which the composition started, but here it is on the melancholic context.

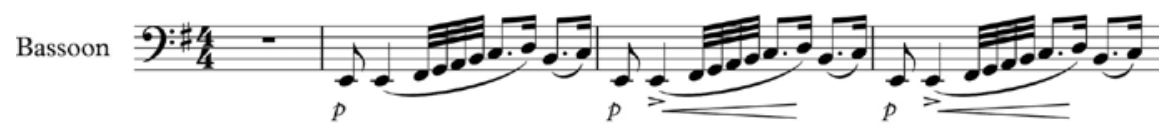

Ex. 5 Syncopated ostinato melody model in bassoon that accompanies the first half of the code (bars 576-579), the part Andante Maestoso from The Sea. ČIURLIONIS, Mikalojus Konstantinas. The Sea. [orchestral score] Leningrad: Muzyka, 1965.

The archetypal sensuality of water in this section is depicted by the dotted rhythms and use of low rhythmic tones that evoke the wavy surface. The static nature and depth of the sea is visualised by a dense score in string instruments, which are entered in the musical record at the lowest point in the score. Although the sea depth is internally formed in the composition score by the moving melodic-rhythmic forms, however, by use of the ostinato rhythmic principle together with minor changes (organ and bassoon), Čiurlionis to a convincingly captures the ambivalence of the sea element. At the middle of the score and sound of the orchestral cloister, the already mentioned citation of the Lithuanian folk song played on the French horn plays a significant role.

The third significant musical and symbolic phenomenon of the first half of the coda is use of the wooden brass instruments. Čiurlionis imitates the single-bar motif from the original first violin also for the flute with piccolo and oboe. Thanks to frequent free bars in the the wooden brass instruments section and small rising sixteenth triplets, the motif acts like continuous surfacing, a twinkling on the vast unending water level and the continuous quoting of folk songs (see Ex. 6). We can again follow this process in the score at the highest placement of the instruments used. Graphically, the instrumentation opens a broad picture of the deep stagnant water (homogeneous string section) with a corrugated movable surface (dominant folk song) and reflections of water waves (high wooden breaths). 


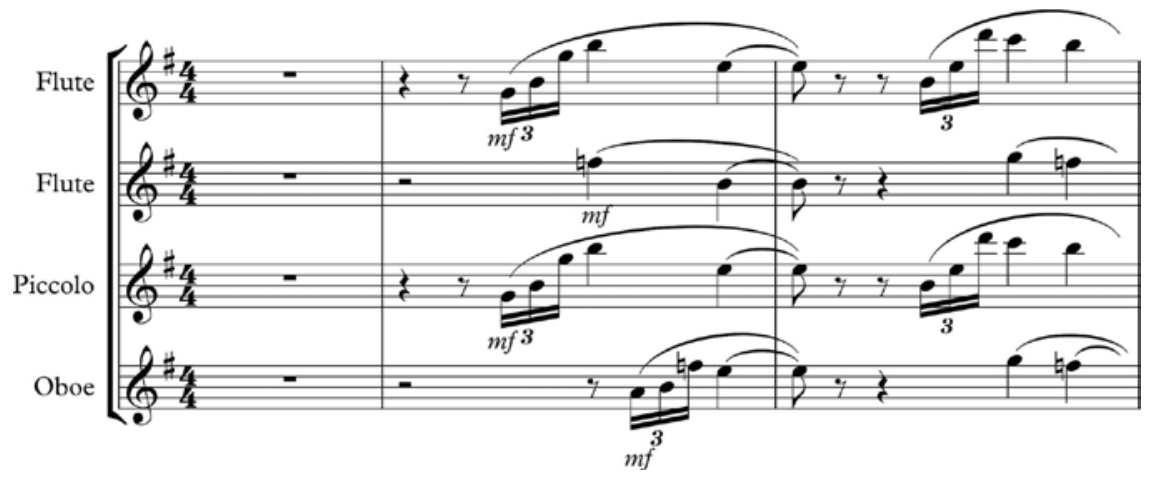

Ex. 6 Imitated motif, symbolisation of the rise of a small wave/twinkle of light (bars 586-588), the part Andante Maestoso from The Sea. ČIURLIONIS, Mikalojus Konstantinas. The Sea.

[orchestral score] Leningrad: Muzyka, 1965.

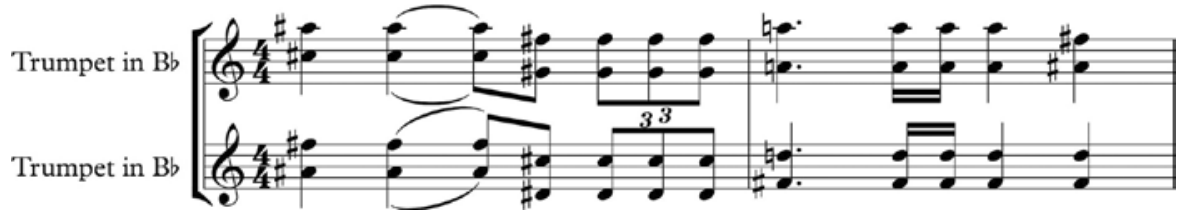

Ex. 7 A demonstration of the "storm" motif in the trumpets (bars 602-603), the part Andante Maestoso from The Sea. ČIURLIONIS, Mikalojus Konstantinas. The Sea. [orchestral score] Leningrad: Muzyka, 1965.

From this sound-specific point (first melancholic half of the coda), Čiurlionis draws close to the end of the composition, which is in contrast grandiose, ceremonial, majestic using full orchestration and a high dynamic cloister. The close of the composition from bar 594 significantly manifests itself as a clear point of light, a celebration, in which the work peaks in the brass instruments section with their twinkling tones. In motivic terms, the preceding musical thinking are returned and mutually interact here; this narratively closes the preceding development of the composition. The dominant instruments become the brass instruments that strongly evoke the ceremonious end (but together with the low positions of the trombones - a reminiscence of the drama of the water element, which has its dark sides). The ceremonial triumphant character of the close of this composition is also accompanied by melodic decorations (trills) in wooden brass and string instruments. The trumpet groups are given rhythm by the "storm" model/motif (see Example 7), which accompanies the symphonic poem at multiple points (particularly in the development section). The motif gradually transcends ("floats") through the imitations in further instruments. ${ }^{22}$ In terms of significance, the storm refers to the process of enlightenment and life cycle related to the resurrection. The storm is a mythical resource for floods, flooding of the existing. Flood is symbolically related to the end and renewal.

22 In the cited study Keym does a more detailed analysis of the musical idea material. 
The transition from the sinister musical flow to the majestic sound conclusion also refers to the spiritual plane of the transition, as transition from one world to another. The transition is associated with the symbol of the bridge, bridging to a higher level of consciousness, from the earthly world to the heavenly world. The entire closing part of Andante maestoso (coda) is summarised in two major content polarities of the sea. The dangers and mysteriousness of the ending beauty of another world, seascapes, the open water areas. The water itself also contains duality and is the cause of all origins, but it also brings destruction.

The mythologically large water areas are often associated with the Great Mother, the symbol of the cycle of life, the queen of all the elements and all spiritual things.

\section{Conclusions}

The symphonic poem The Sea by Lithuanian composer M. K. Čiurlionis shows the musical characteristics of Late Romanticism, but also the composer's specific procedures, which are possibly related to the archetypal background of the entire composition. The inspiring source was the Sea water element with its ambivalent manifestations. The characteristic phenomena of the The Sea include the slow ostinati with quarto and quint intervals, symbolising of the sea waves in the form of scaled musical passages and iconic progress of the melodies in the form of a dotted rhythm and arched melodies. The composition is typical by its frequent tempo oscillations and nuances. The Sea is based on short motifs, which are elaborated into longer music sections through evolutionary changes and transformations, last but not least using ostinato figures in the vertical and horizontal plane of the orchestral score. The inspiration of the archetypal theme of the water element in sheet music is also accentuated by its visual plane, in which thanks to the linear guidance of individual themes, alternation of instrument groups in the ostinati rhythms and chords used, clear visual image of the dynamic sea element. The cyclical character of the archetypal symbol of water (variability of life, rebirth) as an element that corresponds with the cyclical character of the freely used sonata form and motivic development of the composition. The Sea by synthetic music expresses the inconsistency of the water element, it represents the duality of good and evil, birth and death as high tide and low tide, peaceful sections and stormy scenes. By this Čiurlionis refers to the transcendent life cycle in connection with the sea as an aesthetic source of his artistic imagination. Further levels of this multi-layer work are the national aspects of the composition, the folklore thinking of the composer and his inclination to philosophical thinking. Here, the initially romantic inspiration from the water natural element, passes into substantively serious message of philosophical nature with a strong archetypal, and thus universal and culturally communicative content. In the case of Čiurlionis' composition The Sea it is possible to talk about the composer's distinctly modern music thinking, which by its musical and archetypal symbolism transcends the concept of late romantic symphonic poem and the onomatopoeia plane toward advanced symphonism and mu- 
sical symbolism. The applied archetypal approach to the analysis and interpretation indicated the potential relationship between the dynamism of the archetype water and musical express resources. More detailed conclusions shall require the presentation of addition, more complex analytical examples.

The study was supported by the student grant competition of the specific university research project of the University of Ostrava SGS01/PdF/2019 Archetypálni symboly $v$ dile Mikaloje Konstantina Čiurlionse (Archetypal Symbols in the Work of Mikalojus Konstantinas Čiurlionis).

\section{Bibliography}

ADAMENKO, Victoria. Neo-Mythologism in Music. From Scriabin and Schoenberg to Schnittke and Crumb. NY, Hillsdale: Pendragon Press, 2007.

ARIAS, Enrique Alberto. Sublimity and Nature: M. K. Čiurlionisś Jura. Lituanus Lithuanian Quarterly Journal of Arts and Sciences [online]. 2001, Vol. 47, No. 3. [2019-10-12]. http://www.lituanus. org/2001/01_3_04.htm.

BACHELARD, Gaston. Water and Dreams: An Essay on the Imagination of Matter. Texas, Dallas: Dallas Inst Humanities \& Culture, 1999.

ČIURLIONIS, Mikalojus Konstantinas. Čiurlionis simfoninés poemos. [CD audio]. Lithuanian National Symphony Orchestra. Vilnius: Impetus musicus, 2012.

ČIURLIONIS, Mikalojus Konstantinas. The Sea. [orchestral score] Leningrad: Muzyka, 1965.

DAUNORAVIČIENĖ, Gražina - Rima POVILIONIENĖ. Mikalojus Konstantinas Čiurlionis (18751911): jo laikas ir mūsu laikas : stduiju ir mokslo straipsniu rinkinys. Vilnius: Lietuvos muzikos ir teatro akademija, 2013.

Dialogues of Colour and Sound: Works by Mikalojus Konstantinas Ciurlionis and His Contemporaries. Lithuanian Art Museum, 2009.

GOŠTAUTAS, Stasys - Birutė VAIČJURGIS-ŠLEŽAS. Čiurlionis: painter and composer : collected essays and notes, 1906-1989, with 209 illustrations. Vilnius: Vaga, 1994.

JUNG, Carl Gustav. Symbols of Transformation. Collected Works Volume Five. New York: Routledge, 1956.

JUNG, Carl Gustav. The Archetypes and the Collective Unconscious. Princeton: Princeton University Press, 1969.

JUNG, Carl Gustav et al. Man and his Symbols. New York: Dell Publishing Company, 1968.

KALNICKÁ, Zdeňka. Water and Woman: Symbolic-Aesthetic Archetype. Berlin: VDM publishing house Itd., 2010.

KANDINSKY, Wassily. Point and Line to Plane. New York: Solomoner R. Guggenheim Foundation New York, 1947.

KAZOKAS, Genovaité. Musical Paintings: Life and Workof M. K. Čiurlionis (1875-1911). Vilnius: Logotipas, 2009.

KEYM, Stefan. Landschaftsmalerei versus Sonatenform. Die symphonischen Dichtungen Miške und Jura von M. K. Čiurlionis. Musicology of Lithuania/Lietuvos muzikologija, 2009, t. 10., pp. 8-28.

KIMBRYS, Petras. Mikalojus Konstantinas Čiurlionis: twórczość, osobowość, środowisko. Nacionalinis M.

K. Čiurlionio dailès muziejus, 2001. 
KOZEL, David. Mythological Archetype in Music and Principles of its Interpretation. International Review of the Aesthetics and Sociology of Music, 2016, Vol. 47, No. 1, pp. 3-15.

LANDSBERGIS, Vytautas. M. K. Čiurlionis: Time and Content. Vilnius: Lituanus, 1992.

RESPIGHI, Ottorino. Trittico Botticelliano. [orchestral score]. Milan: Ricordi, 1928.

TARASTI, Eero. Myth and Music: A Semiotic Approach to the Aesthetics of Myth in Music, especially that of Wagner, Sibelius and Stravinsky. Helsinki: Suomen Musiik kitieteellien Seura, 1978.

TARASTI, Eero. Semiotics of Classical Music: How Mozart, Brahms and Wagner Talk to Us. Berlin: De Gruyter, 2012. 